\title{
In Vitro and In Vivo Management of Alternaria Leaf Spot of Brassica campestris L.
}

\section{Aqeel Ahmad and Yaseen Ashraf*}

Institute of Agricultural Sciences, University of the Punjab, Lahore-54590, Pakistan

\begin{abstract}
Alternaria black leaf spot caused by Alternaria brassicae is one of the most destructive disease of brassicaceae crops and causes 30 to $45 \%$ overall yield loss in the world.

Plant susceptibility toward this saprophytic and necrotrophic pathogen is greatly influenced by extreme weather conditions e.g. temperature and humidity.

Six plant extracts, six Biological agents and six fungicides were evaluated both in vitro and in vivo experiment for their effectiveness to manage Alternaria leaf spot of Brassica campestris. In cause of in vitro pathogenic fungus was applied in the field at $2 \mathrm{~g}$ colonized mustard seeds $\mathrm{kg}-1$ soil. plant extract, Biological agents and six fungicides were evaluated for their efficacy at various concentrations $5 \%, 10 \%, 15 \%$ and were sprayed in the field at $0.2 \%$ a.i. I-1. Out of all treatments, Allium sativum, Parthenium hysterophorus, Trichoderma harzianum, Trichoderma viride, Wisdom (50\% WP) and Proctor $(60 \% \mathrm{WP})$ were screen out in laboratory at $15 \%$ concentration. The maximum growth inhibition (in laboratory $57.83 \%$, in field $6.07 \%$ and in greenhouse $26.32 \%$ ) was recorded by Allium sativum followed by Parthenium hysterophorus (in laboratory $53.01 \%$, in field $17.05 \%$, in green and house $29.08 \%$ ). Out all biological agents, the maximum growth inhibition (in laboratory $61.44 \%$, in field $27.34 \%$ and in greenhouse $38.45 \%$ ) by Trichoderma harzianum followed by Trichoderma viride (in laboratory $55.42 \%$, in field $29.63 \%$, in green and house $29.08 \%$ ). Out of all fungicides, the maximum growth inhibition (in laboratory $98.79 \%$, in field $56.08 \%$ and in greenhouse $63 \%$ ) by Wisdom (50\% WP) and followed by Proctor (60\% WP) (in laboratory $100 \%$, in field $51.76 \%$ and in greenhouse $55.16 \%)$. It was worth noting that the fungicides, Wisdom (50\% WP) and Proctor (60\% WP) have highest net value as compare to other treatments but the biological agents also show off their importance.
\end{abstract}

Keywords: Alternaria leaf spot; In vitro and in vivo management of Alternaria leaf spot by plant extracts; Biological agents and chemicals

\section{Introduction}

The origin of mustard (Brassica compestris L.) lies in south-east Asia [1]. Mustard is one of most important and oldest known oil seed crop of subcontinent with global contribution of $28.3 \%$ acreage and $19 \%$ of production [2]. Its oils contain low erusic acid and glucosinolates contents. The percentage of poly-unsaturated fatty acid and linolenic acid of the total fatty acid increase from $15-0 \%$ and from $8-12 \%$, respectively [3].

Among the biotic stress of Alternaria leaf of mustard and the causal agent is Alternaria brassicae. It has been reported from all the continents of the world and is one among the important diseases of mustard causing up to $47 \%$ yield losses [4]. Different species of Alternaria on Brassica spp. vary in host specificity. Alternaria brassicae also depending on host susceptibility and environmental factors [5]. Alternaria brassicae infected the plant at all growth stages. Fungus infect all parts of plant as leaves, pods, branches, pods and stem but the special target point of fungus are leaves and pods. Often lesions are produced on green leaves and during sever attack in pods seeds become shrivel and early ripening or shattering [6]. Conventionally plant diseases are controlled by applying fungicides, but this practice increase input cost on the crop on one hand and on the other hand cause environmental pollution [7]. So this situation compels to focus on disease management by utilizing biological agents, plant extracts and fungicides in lowest concentration. Application of biological agents and extract is eco-friendly and a sustainable approach apart from being a promising alternative to fungicide application. In the absence of resistant cultivars, chemical fungicides provide the most reliable means of disease control. The present study was aimed at determining a costeffective management of Alternaria leaf spot.

\section{Material and Method}

\section{Study area and sampling}

In 2012, eight brassicae fields were visited, randomly diseased samples were chosen. A survey was conducted at eight different locations in district Lahore for prevalence, severity and mortality of Alternaria leaf spot of mustard at maturity of mustard crop during cropping season. To assess disease prevalence, severity and mortality, and ten plants were selected in each quadrate in a diagonal configuration depending on the geometry of the field. The following formula was calculated percentage prevalence.

$$
\begin{aligned}
& \text { Prevalence }(\%)=\frac{\text { Locations with disease symptoms }}{\text { Total Locations }} \times 100 \\
& \text { Severity }(\%)=\frac{\text { Sum of rating scale }}{\text { Total number of leaves observed }} \times 100 \\
& \text { Mortality }(\%)=\frac{\text { Sum of dead plants }}{\text { Total plants }} \times 100
\end{aligned}
$$

Alternaria leaf spot disease was collected randomly, with at least five lesions in the leaf blade. From each of the five lesions per leaf,

*Corresponding author: Yaseen Ashraf, Institute of Agricultural Sciences University of the Punjab, Lahore-54590, Pakistan, Tel: +923074826093; E-mail: yaseenashraf00@gmail.com

Received July 04, 2016; Accepted July 20, 2016; Published July 22, 2016

Citation: Ahmad A, Ashraf Y (2016) In Vitro and In Vivo Management of Alternaria Leaf Spot of Brassica campestris L.. J Plant Pathol Microbiol 7: 365. doi: 10.4172/2157-7471.1000365

Copyright: ( 2016 Ahmad A, et al. This is an open-access article distributed under the terms of the Creative Commons Attribution License, which permits unrestricted use, distribution, and reproduction in any medium, provided the original author and source are credited. 
fragments of tissues containing fungi structures were taken out and microscope preparations on glass slides containing a drop of blue Aman were made. The slides were, afterwards, observed in optical microscope at $400 \mathrm{X}$ magnification. Identification was made according to literature [8-10]. After identification, pure cultures were submitted in Pakistan First Fungal Culture Bank Institute of Agriculture Science, University of the Punjab, Lahore.

\section{In vitro screening of treatments}

Alternaria brassicae inhibitory effect was checked against different plants extract in laboratory under food poisoning technique. The food poisoning technique was adopted for invitro testing of biological agents and fungicides. For this purpose, six plants were selected Coronopus didymus (Leaves), Medicago sativa (Leaves), Zingiber officinale (Bulb), Chenopodium hirsutum (Leaves), Allium sativum (Bulb) and Parthenium hysterophorus (Leaves). Ten grams of plants relevant part were grinded with help of pistol and mortal by adding equal amount of distal water $(1: 1 \mathrm{w} / \mathrm{v})$. At last extract was filter with the help of muslin cloth. Aqueous solution (100\%) was obtained. Further, the extract was diluted by adding sterilized water to get 10 percent concentration. Future plants extract were need to heat at $50^{\circ} \mathrm{C}$ to avoid contamination. $2 \mathrm{ml}$ plant extract was poured in $20 \mathrm{ml}$ MEA petriplate and gently shake both for mixing of plants extract in media. When MEA and plants extract solidified then $8 \mathrm{~mm}$ disc of 10 days old pathogen was placed in center of every petriplate. All pertiplates were incubated at $23^{\circ} \mathrm{C}$ for 10 days. Growth inhibition of pathogen, inoculated and uninoculated was calculated according to the formula given by Vincent.

$\%$ Inhibition over control: $\frac{\mathrm{C}-\mathrm{T}}{\mathrm{C}} \times 100$

Where;

\section{$\mathrm{I}=$ Percent inhibition}

$\mathrm{C}=$ Growth in control

$\mathrm{T}=$ Growth in treatments

Biological agents (Trichoderma viride, Trichoderma harzianum, Trichoderma hamatum, Trichoderma koningii, Trichoderma reesei and Trichoderma aureoviride) were obtained from Fungal Culture Bank of Pakistan Institute of Agriculture Science, University of the Punjab, Lahore. These biological agents were screened in laboratory condition against Alternaria brassice. Culture of both pathogen and biological agents $(8 \mathrm{~mm})$ were collected from margin of actively growing mycelium and transfer to MEA medium on opposite site of about at 1 $\mathrm{cm}$ from wall of the plate. The petriplates were subsequently incubated at $25 \pm 1^{\circ} \mathrm{C}$. After 5 days fungal colonies were observed and recorded.

Fungicides inhibitory assessment against $A$. brassicae was performed in laboratory by food poisoning technique. Seven fungicides Ridomil (20\% WP), Diesomil (30\% WP), Topsin-M (45\% WP), Thiram (35\% WP), Dolomile (30\% WP), wisdom (50\% WP) and Proctor (60\% WP) were used for confirmation of efficacy against A.brassicae under invitro conditions. All selected fungicides were tested at $0.1 \%$ concentration. Two $\mathrm{ml}$ of each fungicide were incorporated in sterilized petriplates and gently mixed it. After solidifying MEA media, $8 \mathrm{~mm}$ disc of ten days old sporulating culture of Alternaria brassice was inoculated in center of every petriplate. Controls were maintained. Inoculated petriplates were incubated at room temperature $28^{\circ} \mathrm{C}$ in the laboratory. The colony diameters were measured after 10 days when the control plates were full of fungal growth.

\section{Green house experiment}

Pots having $25 \mathrm{~cm}$ depth and $20 \mathrm{~cm}$ diameter were used. Each treatment was replicated thrice. Sandy loam soil was used and each pot was filled with $10 \mathrm{Kg}$ sterilized soil. Seed were sown in pots at the depth of $2 \mathrm{~cm}$ in January 16, 2016. Three seeds per pot were sown. Pots were irrigated twice in a week. Green house plants become 2 to 3 leaf stage then pathogen inoculated in form of suspension in February, 72016. Inoculum was obtained from culture of Alternaria brassicae grown on malt extract agar. Inoculum was prepared in suspension form, 10 $\mathrm{ml}$ sterile water added in petriplates and shake well. The numbers of spores were counted with heamocytometer and spores were adjusted to $32 \times 10^{7}$ sporesml $^{-1}$.

About $500 \mathrm{ml}$ of inoculums suspension is used with sprayers that run off from top of leaf.

After two weeks leaves established disease symptoms. Older leaves were more severely infected from Alternaria leaf spot as compare to younger leaves. Initially leaves beared light brown lesion which gradually become dark brown and at last dark spot on whole leaf. In severe condition, gradually it spread to other parts of plants such as pods, stem and branches.

\section{Disease management}

The fresh plants extracts (Allium sativum, bulb and Parthenium hysterophorus, leaves) were gently washed under tap water and finally in sterile distilled water. They were separately grind in sterile water at the rate of $1 \mathrm{mlg}^{-1}$ of plant material in pistal and mortal. Then it stained through double layer of muslin cloth and finally through sterilized whatman no. 1 filter paper. This formed $100 \%$ standard plant extract solution. Further its dilution performed of required concentration with sterilized water [11]. Plants extract application at 5\%,10\% and $15 \%$ concentrations.

One week old culture of Trichoderma harzianum and Trichoderma viride were obtained from FCBP. The spore's concentration was adjusted to $32 \times 10^{6}$ spores $\mathrm{ml}^{-1}$ by hemocytometer. Biological agent's was applied at $5 \%, 10 \%$ and $15 \%$ concentrations. Fungicides with recommended dozes were used that are available in market and Spray in field at $5 \%, 10 \%$ and $15 \%$ concentrations.

\section{Field experiment}

The experiment was conducted by randomized block design (RBD) with three replications and the sowing was done om $10 \mathrm{~m} \times 15 \mathrm{~m}$ plots, with a spacing of $90 \mathrm{~cm} \times 60 \mathrm{~m}$ on 2015 and 2016 .

Plants were inoculated with a suspension of pathogen (Alternaria brassicae) at February 7 2016. The spore suspensions of pathogens performed as in green house experiment and application according to section about $2000 \mathrm{ml}$ of inoculums suspension is used with hand sprayers that run off from top of leaf.

\section{Disease management}

Plant extract preparation and application was as discussed in green house experiment. Biological agents preparation and application was as discussed in green house experiment. Fungicides preparation and application was as discussed in section greenhouse experiment.

\section{Statistical analysis}

Treatment mean and standard error were calculated from the data obtained for various parameters using package Costat version 3.03.

\section{Results}

\section{Disease survey}

After peripatetic survey prevalence, severity and mortality of 
Citation: Ahmad A, Ashraf Y (2016) In Vitro and In Vivo Management of Alternaria Leaf Spot of Brassica campestris L.. J Plant Pathol Microbiol 7: 365. doi: 10.4172/2157-7471.1000365

Alternaria black spot disease was recorded. The disease prevalence percentage ranged between 20 to 60 at different locations. The maximum prevalence was $(60 \%)$ recorded at P.U campus and minimum (20\%) recorded at Multan road (Sunder) and G.T road (Rana town). Disease severity percentage was range between 30 to 70 at different locations. The maximum severity $(70 \%)$ was recorded at P.U campus and minimum (30\%) was recorded at G.T road (Rana town) and Raiwind road (Bubtiya chowk). Mortality was ranged between 8 to 25 percent at different locations. The maximum mortality was (25\%) recorded at P.U campus and minimum was $8 \%$ recorded at G.T road (Rana town) (Figure 1).

\section{In vitro screening of treatment against Alternaria brassicae}

Six plants extract (Parthenium hysterophorus, Coronopus didymus, Medicago sativa, Chenopodium hirsutum, Zingiber officinale and Allium sativum) were tested against Alternaria brassicae growth. According to result shown in Figure 2, fungal growth inhibition ranged between $53.01 \%$ to $57.83 \%$. The maximum growth inhibition $(57.83 \%)$ was recorded by Parthenium hysterophorus, followed by Allium sativum (53.01\%). Chenopodium hirsutum inhibited (39.75\%) followed by Medicago sativa (38.55\%). The minimum growth inhibition (30.12\%) was recorded by Zingiber officinale followed by Coronopus didymus (24.93\%).
Six biological agents (Trichoderma harzianum, Trichoderma reesei, Trichoderma viride, Trichoderma aureoviride, Trichoderma konngii and Trichoderma hamatum) were tested for their antifungal activity against Alternaria brassicae. According to results shown in Figure 3, fungal growth inhibition ranged recorded between 15.23 to $61.44 \%$. The maximum growth inhibition (61.44\%) was recorded by Trichoderma harzianum followed by Trichoderma viride (55.42\%) and Trichoderma konngii (40.96\%). Meanwhile, Trichoderma reesei inhibited (33.01\%) followed by Trichoderma hamatum (31.32\%). The minimum growth inhibition (15.90\%) was recorded by Trichoderma aureoviride.

Seven fungicides (Ridomil, Diesomil, Topsin-M, Thiram, Dolomile, Wisdom and Proctor) were tested against Alternaria brassicae growth According to results shown in Figure 4, fungal growth inhibition ranged between 63.85 to 100 percent. The maximum growth inhibition $(100 \%)$ was recorded by proctor. Wisdom inhibited $(98.79 \%)$ growth at $0.1 \%$ concentration followed by Topim $(81.52 \%)$. Dolomile inhibited $75.90 \%$ followed by Ridomil $72.28 \%$. The minimum growth inhibition (69.87\%) was recorded by Diesomil followed by Thirm (63.85\%).

Field and green house studies for prevalence, severity and mortality of Brasscia compestris

From data observation, in field mean disease prevalence, severity and mortality were recorded ( $40 \%, 55 \%$ and $15 \%$ respectively) followed

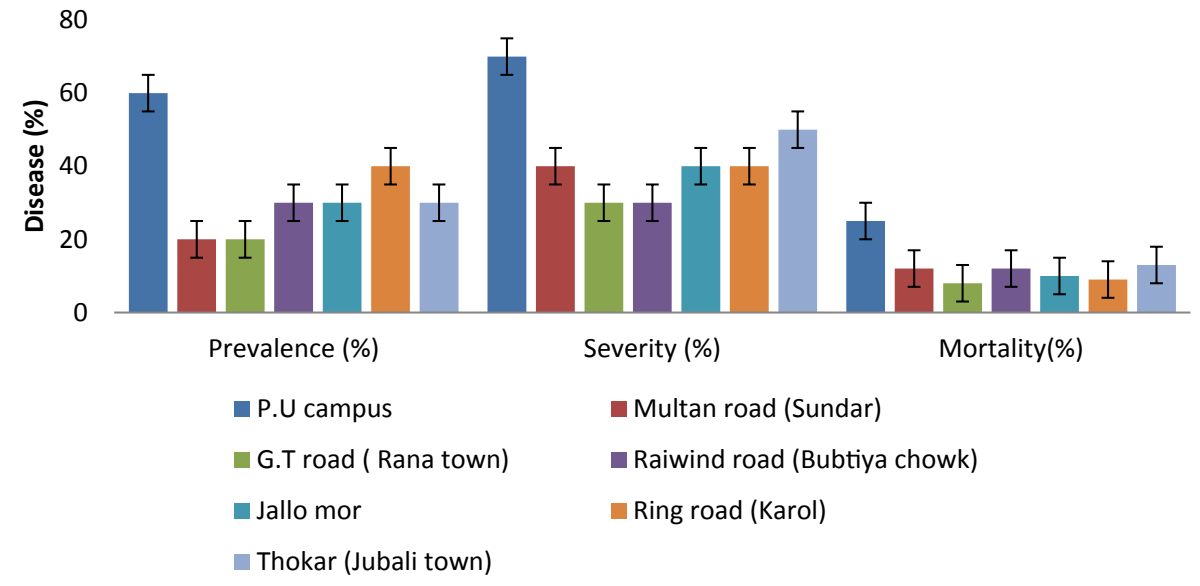

Figure 1: Prevalence (\%), severity (\%) and mortality (\%) of Alternaria leaf spot of mustered at seven different survey location.

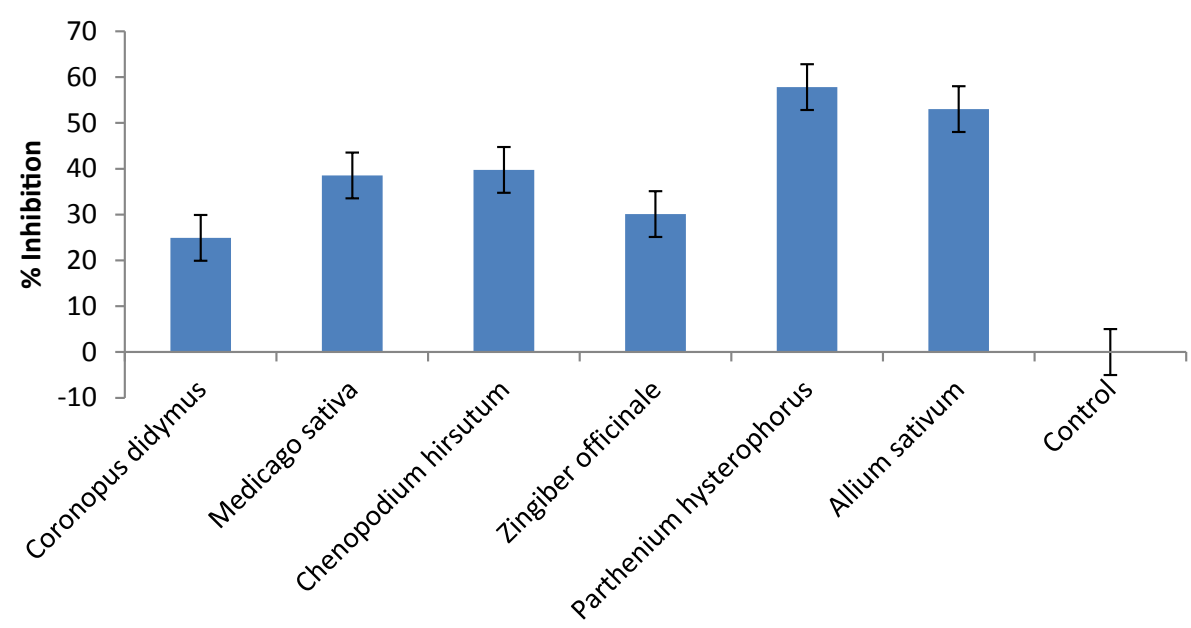

Figure 2: In vitro screening of plant extracts. 
Citation: Ahmad A, Ashraf Y (2016) In Vitro and In Vivo Management of Alternaria Leaf Spot of Brassica campestris L.. J Plant Pathol Microbiol 7: 365. doi: $10.4172 / 2157-7471.1000365$

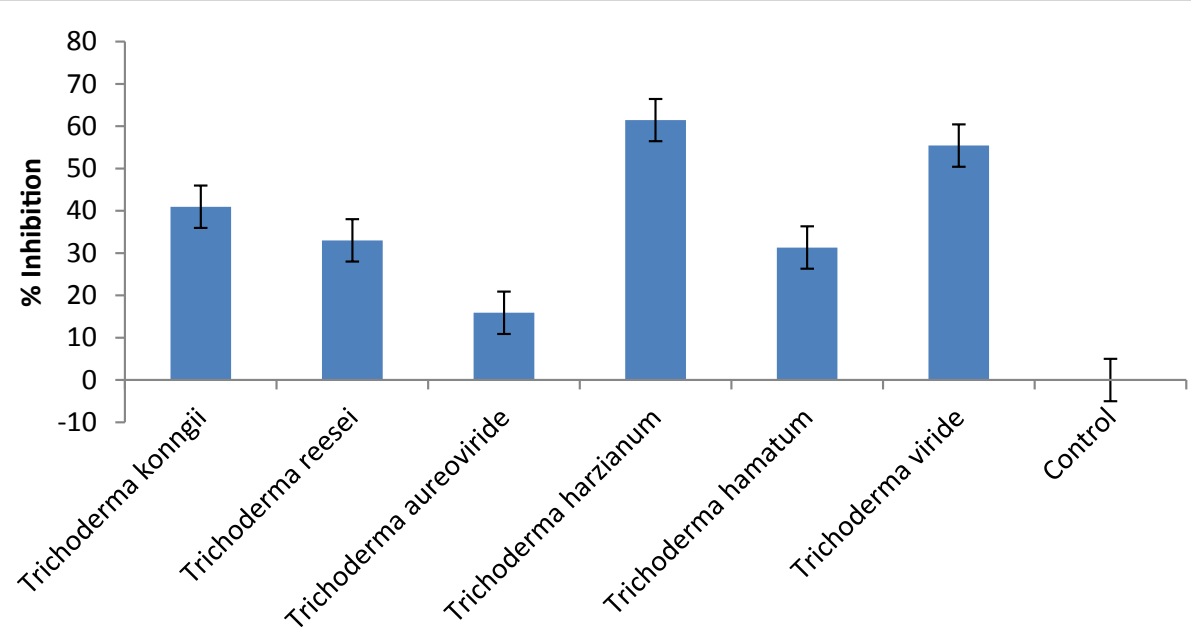

Figure 3: In vitro screening of Biological agents.

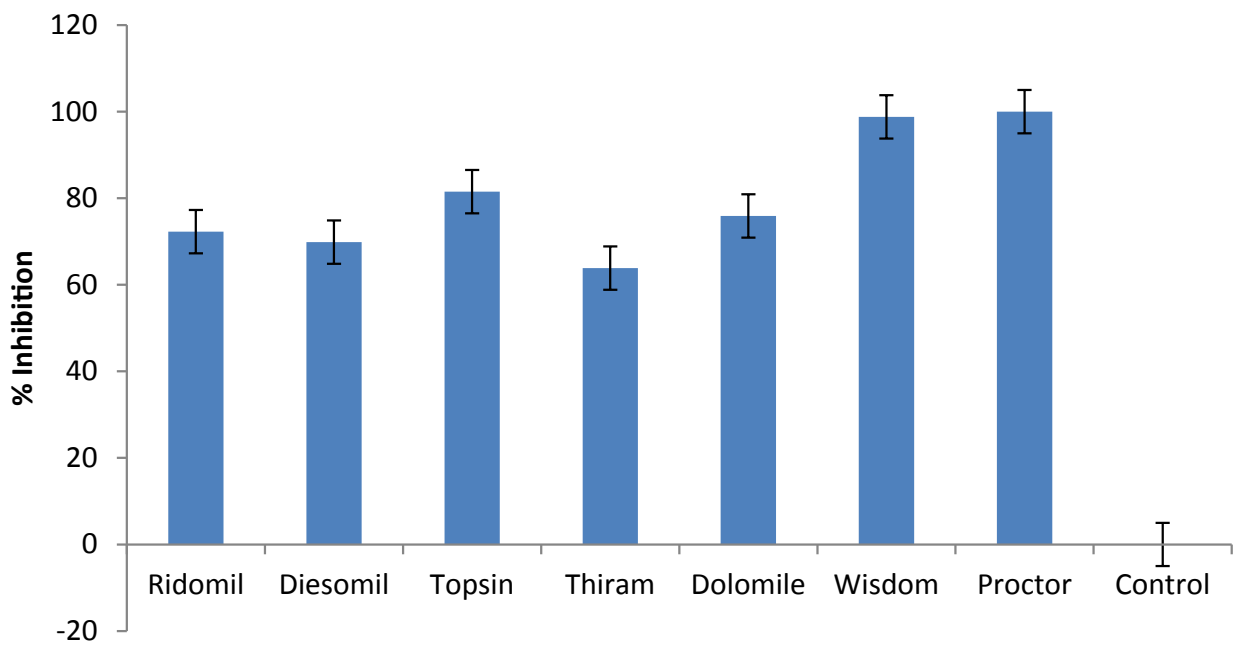

Figure 4: In vitro screening of Fungicide.

by control $(4 \%, 2 \%$ and $0 \%$ respectively). In green house mean disease prevalence, severity and mortality were recorded $(50 \%, 50 \%$ and $10 \%$ respectively) followed by control (3\%, $1 \%$ and $0 \%$ respectively) (Figure 5). Field symptoms categories according to disease rating scale (Plate. 4) and plant disease index was calculated by the following formula;

$$
\text { Plant Disease index }(\%)=\frac{\text { Sum of numerical rating }}{\text { Number of leaves infected }} \times 100
$$

\section{Disease management in field}

Field experiment for management of Alternaria leaf spot of Brasscia compestris: After disease management according to result shown that maximum PDI was $(88.02 \%)$ recorded in plot of control followed by Allium sativum (81.43\%), Parthenium hysterophorus (70.7\%), Trichoderma harzianum (60.86\%), Trichoderma viride (58.57\%), Proctor $(36.44 \%)$ and minimum PDI was recorded by Wisdom (32.12\%).

The maximum leaf spot disease $(56.08 \%)$ was reduces in plot treated with $5 \%, 10 \%$ and $15 \%$ concentration of Wisdom, followed by Proctor (51.76\%), Trichoderma viride (29.63\%), Trichoderma harzianum (27.34\%), and Parthenium hysterophorus (17.5\%) Allium sativum (6.77\%); whereas no any disease reduction was recorded at untreated plot (Table 1).

Green house disease management: After disease management according to result shown that maximum PDI was (86.66\%) recorded in plot of control followed by Allium sativum (60.34\%), Parthenium hysterophorus (56.86\%), Trichoderma harzianum (48.5\%), Trichoderma viride $(48.14 \%)$, Proctor (31.5\%) and minimum PDI was recorded by Wisdom (23.66\%).

The maximum leaf spot disease $(63 \%)$ was reduces in plot treated with Wisdom, followed by Proctor (55.16\%), Trichoderma viride (38.16\%), Trichoderma harzianum (38.45\%), and Parthenium hysterophorus (38.45\%) Allium sativum (26.32\%); whereas no any disease reduced was recorded in plants not sprayed with fungicides (Table 2).

\section{Discussion}

Disease prevalence ranged between 20 to $60 \%$ followed by severity 30 to $70 \%$ and mortality 25 to $8 \%$ at different locations. Maximum disease prevalence, severity and mortality (60, 70 and $25 \%$ respectively) were recorded at P.U campus followed by Thokar (30, 50 and $12 \%$ 
Citation: Ahmad A, Ashraf Y (2016) In Vitro and In Vivo Management of Alternaria Leaf Spot of Brassica campestris L.. J Plant Pathol Microbiol 7: 365. doi: $10.4172 / 2157-7471.1000365$

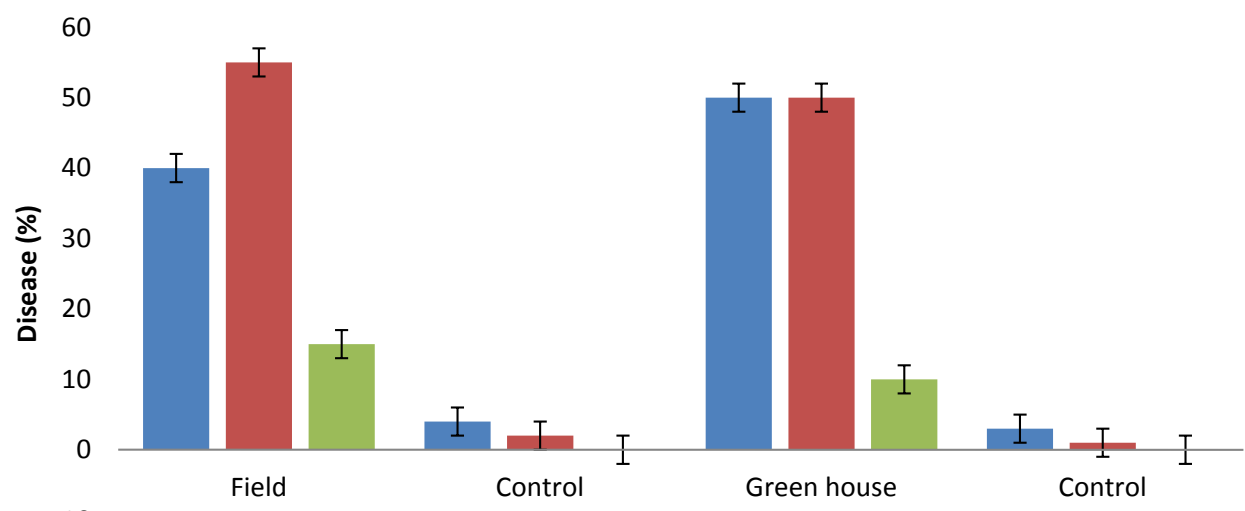

Prevalence (\%) - Severity (\%) Mortality(\%)

Figure 5: Alternaria leaf spot disease in field and green house.

\begin{tabular}{|c|c|c|c|c|c|c|c|c|c|c|c|c|c|c|}
\hline \multirow{3}{*}{$\begin{array}{l}\text { Nature of } \\
\text { Treatments }\end{array}$} & \multicolumn{14}{|c|}{ Alternaria Leaf spot } \\
\hline & \multicolumn{4}{|c|}{ Replicate 1} & \multicolumn{4}{|c|}{ Replicate 2} & \multicolumn{4}{|c|}{ Replicate 3} & \multirow{2}{*}{ \%PDI } & \multirow{2}{*}{$\%$ Decrease } \\
\hline & $5 \%$ & $10 \%$ & $15 \%$ & Mean & $5 \%$ & $10 \%$ & $15 \%$ & Mean & $5 \%$ & $10 \%$ & $15 \%$ & Mean & & \\
\hline Allium sativum & 80 & 72 & 64 & $70 \pm 2.42$ & 81 & 73 & 65 & $73 \pm 3.97$ & 79 & 71 & 62 & $70.66 \pm 3.10$ & $81.43 \pm 5.02$ & $6.77 \pm 0.02$ \\
\hline $\begin{array}{c}\text { Parthenium } \\
\text { hysterophorus }\end{array}$ & 74 & 64 & 49 & $60.4 \pm 2.04$ & 75 & 65 & 50 & $63.4 \pm 3.31$ & 73 & 62 & 49 & $61.33 \pm 2.21$ & $70.7 \pm 4.41$ & $17.5 \pm 0.09$ \\
\hline $\begin{array}{l}\text { Trichoderma } \\
\text { harzianum }\end{array}$ & 63 & 54 & 44 & $51.7 \pm 1.54$ & 64 & 55 & 45 & $54.7 \pm 2.30$ & 62 & 52 & 44 & $52.67 \pm 1.90$ & $60.86 \pm 3.92$ & $27.34 \pm 0.91$ \\
\hline Trichoderma viride & 64 & 49 & 43 & $50 \pm 1.52$ & 65 & 50 & 44 & $53 \pm 2.21$ & 61 & 48 & 42 & $50.34 \pm 1.12$ & $58.57 \pm 2.41$ & $29.63 \pm 2.08$ \\
\hline Wisdom & 41 & 34 & 09 & $26 \pm 0.01$ & 42 & 35 & 10 & $29 \pm 0.04$ & 40 & 33 & 10 & $27.67 \pm 0.03$ & $32.12 \pm 0.02$ & $56.08 \pm 3.41$ \\
\hline Proctor & 39 & 44 & 19 & $28.6 \pm 0.08$ & 40 & 45 & 20 & $31.6 \pm 0.00$ & 41 & 45 & 23 & $36.33 \pm 0.41$ & $36.44 \pm 0.05$ & $51.76 \pm 2.52$ \\
\hline Untreated Control & 91 & 84 & 90 & $87.4 \pm 3.95$ & 92 & 85 & 90 & $88.4 \pm 5.04$ & 90 & 86 & 88 & $88 \pm 5.41$ & $88.2 \pm 5.92$ & $0 \pm 0.00$ \\
\hline
\end{tabular}

\pm Standard error

Table 1: Field studies for Alternaria leaf spot of Brassica compestris by using plant extract, biological agents and fungicides.

\begin{tabular}{|c|c|c|c|c|c|c|c|c|c|c|c|c|c|c|}
\hline \multirow{3}{*}{ Nature of Treatments } & \multicolumn{14}{|c|}{ Alternaria Leaf spot } \\
\hline & \multicolumn{4}{|c|}{ Replicate 1} & \multicolumn{4}{|c|}{ Replicate 2} & \multicolumn{4}{|c|}{ Replicate 3} & \multirow{2}{*}{ \%PDI } & \multirow{2}{*}{$\%$ Decrease } \\
\hline & $5 \%$ & $10 \%$ & $15 \%$ & Mean & $5 \%$ & $10 \%$ & $15 \%$ & Mean & $5 \%$ & $10 \%$ & $15 \%$ & Mean & & \\
\hline Allium sativum & 69 & 61 & 53 & $61 \pm 1.98$ & 71 & 63 & 55 & $63 \pm 3.49$ & 66 & 57 & 50 & $57.67 \pm 3.14$ & $60.34 \pm 3.90$ & $26.32 \pm 0.02$ \\
\hline $\begin{array}{c}\text { Parthenium } \\
\text { hysterophorus }\end{array}$ & 63 & 57 & 45 & $55 \pm 1.92$ & 65 & 55 & 45 & $55 \pm 2.59$ & 70 & 60 & 46 & $58.67 \pm 3.31$ & $56.86 \pm 3.38$ & $29.8 \pm 0.08$ \\
\hline $\begin{array}{l}\text { Trichoderma } \\
\text { harzianum }\end{array}$ & 52 & 47 & 41 & $46.66 \pm 2.02$ & 54 & 45 & 40 & $46.34 \pm 3.25$ & 60 & 50 & 40 & $50 \pm 2.52$ & $48.21 \pm 3.0$ & $38.45 \pm 1.12$ \\
\hline Trichoderma viride & 53 & 46 & 40 & $47.34 \pm 2.08$ & 55 & 46 & 41 & $47.34 \pm 3.25$ & 61 & 47 & 41 & $49.66 \pm 2.21$ & $48.5 \pm 2.9$ & $38.16 \pm 1.42$ \\
\hline Wisdom & 34 & 26 & 11 & $23.67 \pm 0.02$ & 32 & 26 & 10 & $22.67 \pm 1.35$ & 37 & 27 & 10 & $24.66 \pm 1.91$ & $23.66 \pm 1.95$ & $63 \pm 3.23$ \\
\hline Proctor & 32 & 37 & 19 & $29.33 \pm 0.03$ & 30 & 35 & 17 & $27.33 \pm 2.05$ & 40 & 45 & 22 & $35.67 \pm 2.97$ & $31.5 \pm 2.06$ & $55.16 \pm 2.51$ \\
\hline Untreated Control & 89 & 81 & 88 & $86 \pm 4.95$ & 90 & 80 & 88 & $86 \pm 9.82$ & 87 & 85 & 90 & $87.33 \pm 5.07$ & $86.66 \pm 6.56$ & $0 \pm 0.00$ \\
\hline
\end{tabular}

\pm Standard error

Table 2: Green house studies for Alternaria leaf spot of Brassica compestris by using plant extract, biological agents and fungicides.

respectively), Multan road (20, 40 and $8 \%$ respectively), Ring road (40, 40 and $12 \%$ respectively), Jallo mor (30, 40 and $10 \%$ respectively), Raiwind raod (30, 30 and $9 \%$ respectively) and minimum disease was (20, 30 and $13 \%$ respectively) recorded at G.T road (Rana town). Similar results were reported by Maltoni et al. [12]

The fungus, Alternaria brassicae was isolated and identified by its morphological characteristics as described by Lelivet. It was confirmed as cause of Alternaria leaf spot disease of Brassica compestris. The findings were conformed from Fungal Culture Bank of Pakistan. Allium sativum and Parthenium hysterophorus was screen out by food poisoning technique. According to data they inhibited maximum (53.01\% and $57.83 \%$ respectively) fungal growth followed by
Trichoderma harzianum and Trichoderma veridie $(61.44 \%$ and $55.42 \%$ respectively) and wisdom and Proctor (98.79\% and 100\% respectively).

Chemical control is ultimate and easy solution of disease. But biological management is more acceptable to environment and human being. Lot of literature is available regarded to justify biological management of Alternaria leaf spot of $B$. compestris. Spray of soil isolates of Trichoderma viride at 45 and 75 days after sowing could manage Alternaria blight of Indian mustard (Brassica juncea) as effectively as mancozeb and other fungicides, which have been incorrigible later in multiplication trials (AICRP-RM, 2007). Botanicals viz., bulb extract of Allium sativum has been reported to effectively manage Alternaria blight of Indian mustard [13]. 
Citation: Ahmad A, Ashraf Y (2016) In Vitro and In Vivo Management of Alternaria Leaf Spot of Brassica campestris L.. J Plant Pathol Microbiol 7: 365. doi: 10.4172/2157-7471.1000365

The maximum leaf spot reduction was $(63 \%)$ recorded of Wisdom followed by Proctor (55.16\%), Trichoderma viride, (38.16\%), Trichoderma harzianum (38.45\%) and minimum disease reduction was recorded from Parthenium hysterophorus (29.8\%) followed by Allium sativum (26.16\%).

Chemical management is most favorable and widely used method against disease. One sided it completely control disease but other hand it has many unseen sides' effects which directly or indirectly transfer to human beings. Meanwhile, it also has hazardous effect in our environment. Although fungicide remains more effective in reducing diseases in plants, increasing public concern about environmental health is proving to be major hindrance in use of chemical pesticides including fungicides.

\section{References}

1. Vavilov NI, Dorofeev VF (1992) Origin and Geography of Cultivated Plants Transl.by Doris Love. Cambridge University Press p: 498.

2. Bandopandopadyay L, Basue D, Sikdar SR (2013) Identification of genes involved in wild Crucifer Rorippa indica resistance response on mustard aphid Lipaphis erysimi challenge. PLoS One 8: e73632.

3. Tayo TO, Morgan DG (1979) Factors influencing flower and pod development in oil-seed rape (Brassica napus). J Agric Sci Cambridge 92: 363-373.
4. Kolte SJ (1985) Diseases of Annual Edible Oilseed Crops, Vol. II, Rapeseed Mustard and Sesame Diseases. CRC Press Inc. Boca Raton, Florida p: 135.

5. Paul VH, Rawlinson CJ (1992) Diseases and Pests of Rape. GelsenkirchenBuer, Germany: Verlag Th. Mann.

6. Conn KL, Tewari JP, Awasthi RP (1990) A Disease Assessment Key for Alternaria Black Spot in Mustard. Can Plant Dis Sur 70: 19-22.

7. Chattopadhyay AK, Bagchi BN (1994) Relationship of disease severity and yield due to leaf blight of mustard and spray schedule ofmancozeb for higher benefit. J Mycopathol Res 32: 83-87.

8. Gilman JC (1945) A manual of Soil Fungi. 2nd ed. The Lowa State University Press, Ames, Lowa, USA.

9. Domsch KH, Gams W, Andreson TH (1980) Compendium of soil fungi. Volume 1. Academic press. A subsidiary of Harcourt braceJovanovich, publishers. London, New York, Toronto, Sydney, SanFrancisco.

10. Barent HL, Hunter BB (2003) Illustrated Genera of Imperfect Fungi. APS Press, The American Phyto pathological society St. Paul, Minnesota.

11. Shekhawat PS, Prasada R (1971) Antifungal properties of some plant extract and inhibition of spores germination. Indain phytopathol 24: 800-802.

12. Maltoni ML, Magnani S, Baruzzi G (2000) Screening forAlternaria black spot resistance in strawberry plants 62: 95-97.

13. Patni CS, Kolte SJ (2006) Effect of some botanicals in management of Alternaria blight ofrapeseed-mustard. Ann PI Prot Sci 14: 151-156. 